\title{
Socio-Economic and Institutional Factors Influencing Adoption of Agroforestry in Arid and Semi Arid (ASALs) Areas of Sub Saharan Africa
}

\author{
Benjamin Mutuku Kinyili1 ${ }^{*}$, Ezekiel Ndunda ${ }^{2}$, Esther Kitur ${ }^{2}$ \\ ${ }^{1}$ Kenya Forest Services, PO Box 2501-30100, Eldoret, Kenya \\ ${ }^{2}$ Department of Environmental Science, Kenyatta University, P.O. Box 43844-00100, Nairobi, Kenya \\ *Corresponding Authors: Benjamin Mutuku Kinyili, Kenya Forest Services, PO Box 2501-30100, \\ Eldoret, Kenya
}

\begin{abstract}
The slow pace in adoption of agroforestry in the Sub Saharan Africa, particularly in arid and semi arid areas (ASALS) warrant an understanding of the underlying factors. Several studies have indicated that in resource limited countries including the ASALs, socio-economic and institutional factors may play a key role in adoption of agricultural production and technologies. Therefore, this study evaluated 16 socioeconomic and institutional factors influencing the adoption of agroforestry in Eastern Kenya within the Sub Saharan Africa. The study used survey research design. Based on a sample of 248 household heads, we gathered data using questionnaires and interviews. The influence of socio-economic factors on adoption was performed using binary logistic regression model. Our results showed that agroforestry was adopted by $82 \%$ of the respondents. The main agroforestry practices adopted by farmers were boundary planting (73.8\%), hedgerow (69.4\%), woodlots (53.2\%), scattered planting (51.2\%) and alley cropping (37.1\%). The levels of education, household size, access to credit, and training were significant $(P<0.05)$ factors influencing the adoption of agroforestry. More resources in the forms of access to credit, inputs and training on agroforestry adoption should be high priority focus to enhance adoption of the practice.
\end{abstract}

Keywords: ASALs, Agroforestry adoption; Socio-economic factors; Institutional factors; Machakos, Kenya

\section{INTRODUCTION}

Due to high productivity and sustainable land use, adoption of agroforestry is ubiquitous at the global scale (Dalemans et al. 2018; Fleming et al. 2019; McAdam and Curran 2018). Studies have shown that groforestry practices slow or reverse land degradation, sequester carbon from the atmosphere and secure rural livelihoods through provision of economic benefits such as increase food security in rural areas (Catacutan et al. 2017; Montagnini and Metzel 2017; Saqib et al. 2019; Sharma and Sharma 2017; Waldron et al. 2017). Trees managed by farmers also provide ecosystem services and functions in addition to the products and services that motivate farmers to plant them (Fagerholm et al. 2016; Kuyah et al. 2017). These services are of particular importance in many low-income countries in Africa, where large proportions of the populations work in an agricultural sector that does not attract much investment from either government or private sector (Benjamin and Sauer 2018; Meijer et al. 2015). The contribution of agroforestry to livelihood especially in the rural areas has witnessed an increased recognition by practitioners (Munsell et al. 2018), and international bodies such as the United Nations and World Bank, ICRAF, government and non-governmental organizations (NGOs) for global adoption of agroforestry (Ajayi and Place 2012; Place et al. 2012). This advocacy has resulted in approximately 350 million agroforestry adopters, who dedicate at least 5 to $10 \%$ of their farms to practice agroforestry (Pattanayak et al. 2003).

Although there has been significant advances in research on agroforestry adoption over the past three to five decades, it is agreeable that adoption of agroforestry including agroforestry practices and technologies have lagged behind the scientific and technological advances in agroforestry research (Dalemans et al. 2019; Kabwe et al. 2016; Mwase et al. 2015). This is particularly true, in the developing countries where agroforestry has lagged behind in its contribution to agricultural productivity, ecosystem services, and human well-being (Miller et al. 2017) as compared to the 
developed countries in Europe and North America (Brockington et al. 2016; Brown et al. 2018; Kalaba et al. 2010; Sangeetha et al. 2016). The underlying factors behind these differences are currently being exploited with broad spectrum of suggestions. Interest in the adoption and practice of agroforestry has increased among smallholder farmers in the developing countries especially in the Sub Saharan Africa (Garrity 2004; Owombo et al. 2018). An active area of research therefore concerns the preconditions that must be met for successful establishment of agroforestry. A major research frontier in agroforestry science is the extrapolation of the influences of locally successful practices, to aid in better understanding of barriers to adoption.

There are numerous studies that have looked at the importance of social and economic factors among households (Alavalapati et al. 2001; Franzel et al. 2002; Matata et al. 2010; Zerihun et al. 2014). There is also increasing recognition that institutions that support agroforestry as well as the institutional factors may have an impact on the adoption of agroforestry among the rural populations (Binam et al. 2017; Mercer 2004). However, there is less emphasis on how combination of socio-economic and institutional factors affect adoption of agroforestry (Alavalapati et al. 2001; Franzel et al. 2001; Matata et al. 2010; Mercer 2004; Mwase et al. 2015). This is particularly lacking in the Sub Saharan Africa where there are numerous constraints to adoption of agroforestry. Therefore the contribution of both socio-economic factors and institutional factors on adoption of agroforestry need to be understood in the local context to better understand the barriers to adoption of agroforestry. Therefore the aim of this study was to model 16 socio-economic and institutional factors affecting adoption of agroforestry in semi arid region of Machakos County in Kenya within the Sub Saharan Africa.

\section{Materials ANd Methods}

\subsection{Study Area}

The study was conducted in Machakos County (Fig. 1) in Kenya. The county covers an area of $5,953 \mathrm{~km}^{2}$. It lies between latitudes $0^{\circ} 45^{\prime}$ South and $1^{\circ} 31^{\prime}$ South and longitudes $36^{\circ} 45^{\prime}$ East and $37^{\circ} 45^{\prime}$ East. Most of the land is semi-arid with population of 1,098,584 as per the 2009 Kenya National census (Kenya National Bureau of Statistics 2010). Administratively the county is divided into 11 divisions: Kalama, Kangundo, Kathiani, Machakos Central, Masinga, Matungulu, Mavoko, Mwala, Ndithini, Yathui and Yatta. In terms of political structure, the county has eight constituencies including: Kangundo, Kathiani, Machakos Town, Masinga, Matungulu, Mavoko, Mwala and Yatta. Division and constituency is sometimes referred to as sub-counties. Agroforestry is practiced in Kathiani, Mavoko and Machakos Town. Four sites selected in this study were: Mua Hills (Mavoko, Machakos Town and Kathiani) and Iveti Hills (Machakos Central and Kathiani), Kima-Kimwe and Kalama in Machakos Town Constituency.

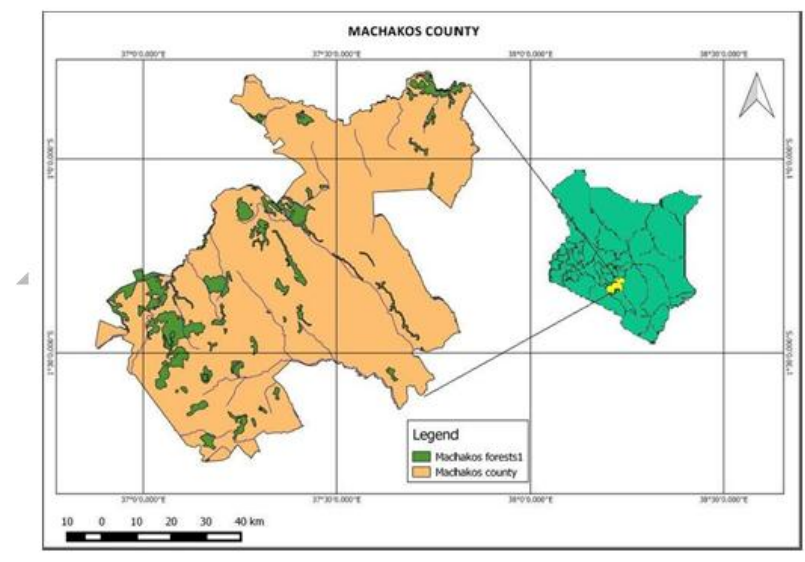

Fig1. Map of Machakos County showing the study area

The local climate is semi-arid with hilly terrain and an altitude of 1000 to $2100 \mathrm{~m}$ above sea level. The area is composed of hilltops rising to $1594-2100 \mathrm{~m}$ above sea level. The annual average rainfall is 1000 $\mathrm{mm}$ (range 500 to $1300 \mathrm{~mm}$ ) with a bimodal pattern. Temperatures range between $18.7^{\circ} \mathrm{C}$ and $29.7^{\circ} \mathrm{C}$. The soils are shallow dark red volcanic on hilltops and clay soils in the plains. Crop such as maize, beans, pigeon peas, vegetables are dominant. Dairy and beef cattle, sheep and goats are the major livestock kept. 


\subsection{Research Design}

This study was conducted using survey design. Surveys are normally used to systematically gather factual quantifiable information necessary for decision-making (Nardi 2018). Surveys are efficient methods of collecting descriptive data regarding the characteristics of populations, current practices and conditions or needs. Survey study research design was adopted in this study to capture descriptive data from selected samples and generalize the findings to the populations from which the sample was drawn.

\subsection{Target Population}

The study targeted household heads from Mua Hills (Mavoko, Machakos Town and Kathiani), Iveti Hills (Machakos Central and Kathiani), Kima-Kimwe and Kalama Hills in Machakos Constituency. The number of farmers practicing agroforestry in the region has not been established.

\subsection{Sample Size and Sampling Design}

Since the actual population was not easy to determine due to changes in the rate of adoption with respect to time, the sample size utilizing proportion of the households adopting agroforestry (Nzilu 2015) was used. According to Nzilu, $80 \%$ of the households had adopted agroforestry in Mwala Constituency (Machakos County). The appropriate sample size was therefore computed using the formula described in (Mugenda and Mugenda 2003) as: $n=\frac{z^{2} p(1-p)}{d^{2}}$

Where: $\mathrm{n}=$ the desired sample size

$\mathrm{z}=$ the $\mathrm{z}$ score at the required confidence level $\alpha=0.05$ (1.96)

$\mathrm{p}=$ the proportion in the target population assumed to be adopters $(0.8)$

$\mathrm{d}=$ permissible marginal error (the level of statistical significance, set at $\alpha=0.05$ ).

Using the values of $z, p$ and $d$, the value of $n$ was computed as follows

$$
\mathrm{n}=\frac{1.96^{2} \times 0.8(1-0.8)}{0.05^{2}}=246
$$

The sample size was 246 in addition to information obtained from 2 research assistants who hailed from the region giving a total of 248 respondents. Samples were selected through stratified, random sampling at each of the selected spatial units and used to identify the adopters and non adopters. Adopters were households practicing any form of agroforestry.

\subsection{Research Instruments and Data Collection}

This study relied on primary data. Data on socio-economic and institutional factors affecting adoption of agroforestry were collected using structured researcher administered questionnaires. The designing of the instruments were such that they endeavored to ensure an in-depth exploration of personal views, feelings and opinions on agroforestry and benefits accrued.

Field surveys of agroforestry adoption were conducted for three months among the selected group of respondents. Identification of agroforestry adopters was conducted by field observation of the households practicing any form of agroforestry. Before data collection, the respondents were contacted in advance and asked to organize their time for the research. Two research assistants were recruited and trained to aid in the collection of data. The questionnaires were administered by physical drop and pick by the researcher and two research assistants. The researcher personally administered the instrument. The researcher made prior visits to assist in defining timings and distribution of the research instruments.

\subsection{Validity and Reliability of the Research Instruments}

The researcher developed the research instruments based on study aim and the related literature. The salience of the instruments was sought through expert judgment. This was to purposely ascertain the item's construct and content validity and to establish whether the numbers of items are adequate for the purpose intended research. 
The reliability of instruments was established through a pilot study in 12 households who did not participate in this study. The results of the study were used to compute the reliability of the instruments. Cronbach's coefficient alpha was used to determine the reliability of the instruments. The study considered the instrument reliable and acceptable if the computation yielded a reliability coefficient of 0.7 and above. For this study, the reliability coefficient was 0.85 which was determined to be suitable for the research.

\subsection{Statistical Analyses}

All questionnaire data were coded into Statistical Package for Social Sciences (SPSS 23.0) for analysis. To test the socio-economic and institutional factors influencing adoption of agroforestry binary logistic regression model was used in testing the probability of dichotomous outcome (in our study, adoption or non-adoption) related to a set of independent explanatory variables that are hypothesized to affect the dependent variable (Harrell 2015). The logistic regression model characterizing agroforestry adoption was specified using the formula: $\ln \left[\mathrm{P}_{\mathrm{i}} /\left(1-\mathrm{P}_{\mathrm{i}}\right)\right]=\beta_{0}+\beta_{1} \mathrm{X}_{1 \mathrm{i}}+\beta_{21} \mathrm{X}_{2 \mathrm{i}}+\ldots+\beta_{\mathrm{k}} \mathrm{X}_{\mathrm{ki}}$

where subscript $i$ is the observation in the ${ }^{i}$ th sample, $\mathrm{P}$ is denotes probability of the outcome, $\beta_{0}$ is the intercept, $\beta_{1}, \beta_{2}, \ldots \beta_{\mathrm{k}}$ are coefficients associated with each explanatory variable $X_{1}, X_{2}, \ldots X_{k}$. The coefficients $\beta_{1}, \beta_{2}, \ldots \beta_{\mathrm{k}}$ reflect the effect of individual explanatory variables on its log of odds $\ln [\mathrm{P} /(1-\mathrm{P})]$. A positive coefficient means that the log of odds increases in tandem with an increase in the corresponding independent variable (Cox 2018). Accordingly, if the log of odds $\ln [\mathrm{P} /(1-\mathrm{P})]$ is positively (or negatively) related to an independent variable, both odds $\ln [\mathrm{P} /(1-\mathrm{P})]$ and $\mathrm{P}$ of the outcome are also positively (or negatively) related to that variable. Nevertheless, this relationship is linear for the log of odds and nonlinear for odds and probability of the outcome. The significance of the variables in the binary logistic regression was tested using Wald statistics. All analyses were declared significant at $P<0.05$.

The independent $\left(\mathrm{X}_{\mathrm{i}}\right)$ variables involved in the logistic regression model for agroforestry adoption are defined in Table 1 . The summary statistics of the independent variables $\left(X_{i}\right)$ in the logistic regression are presented in Table 2.

Table1. Description of explanatory variables used in the agroforestry binary logistic model of adoption model

\begin{tabular}{|c|c|}
\hline Variable & Description \\
\hline Age $\left(\mathrm{X}_{1}\right)$ & Age in years \\
\hline Gender $\left(\mathrm{X}_{2}\right)$ & Value 1 if the respondent is male, 0 otherwise \\
\hline Marital status $\left(\mathrm{X}_{3}\right)$ & Value 1 if the respondent is married, 0 otherwise \\
\hline Level of education $\left(\mathrm{X}_{4}\right)$ & $\begin{array}{l}\text { Index for levels of education: Value } 1 \text { = None; } 2 \text { = Primary; } 3 \text { = Secondary; } \\
4=\text { Tertiary }\end{array}$ \\
\hline Household size $\left(\mathrm{X}_{5}\right)$ & Number of people in the household \\
\hline Land size $\left(\mathrm{X}_{6}\right)$ & Land size in acres \\
\hline Location $\left(\mathrm{X}_{7}\right)$ & $\begin{array}{l}\text { Household residential areas: Index for location 1= Mua Hills; } 2 \text { = Iveti Hills; } \\
3 \text { = Kiima Kimwe Hills; } 4 \text { = Kalama }\end{array}$ \\
\hline $\begin{array}{l}\text { Occupation of the household } \\
\text { head }\left(\mathrm{X}_{8}\right)\end{array}$ & Value 1 if the respondent is a farmer, 0 otherwise \\
\hline Farm household income $\left(\mathrm{X}_{9}\right)$ & Amount of income earned by the respondents from the farms (US $\$$ ) \\
\hline $\begin{array}{l}\text { Non farm household income } \\
\left(\mathrm{X}_{10}\right)\end{array}$ & Amount of income earned by the respondents not from the farms (US $\$$ ) \\
\hline Access to extension services & Value 1 if the respondent had access to information, 0 otherwise \\
\hline Access to credits $\left(\mathrm{X}_{12}\right)$ & Value 1 if the respondent had access to credits, 0 otherwise \\
\hline Access to formal AF training & Value 1 if the respondent had access to agroforestry training, 0 otherwise \\
\hline $\begin{array}{l}\text { Access to information from } \\
\text { conservancy groups }\left(\mathrm{X}_{14}\right)\end{array}$ & $\begin{array}{l}\text { Value } 1 \text { if the respondent had access to information from conservancy } \\
\text { groups, } 0 \text { otherwise }\end{array}$ \\
\hline $\begin{array}{l}\text { Access to inputs from } \\
\text { conservancy groups }\left(\mathrm{X}_{15}\right)\end{array}$ & Value 1 if the respondent had inputs from conservancy groups, 0 otherwise \\
\hline $\begin{array}{l}\text { Frequency of extension visits } \\
\left(\mathrm{X}_{16}\right)\end{array}$ & $\begin{array}{l}\text { Index for extension visits: Value } 1=\text { None; } 2=\text { Rarely; } 3=\text { Yearly; } 4= \\
\text { Monthly; } 5=\text { Often }\end{array}$ \\
\hline
\end{tabular}


Socio-Economic and Institutional Factors Influencing Adoption of Agroforestry in Arid and Semi Arid (ASALs) Areas of Sub Saharan Africa

Table2. Characteristics of agroforestry 'adopter and non-adopter used in the logistic regression model

\begin{tabular}{|l|l|l|}
\hline Variables & $\begin{array}{l}\text { Agroforestry adopters }(\mathrm{n}= \\
204)\end{array}$ & $\begin{array}{l}\text { Agroforestry } \\
\text { adopters }(\mathrm{n}=44)\end{array}$ \\
\hline Age (years) & $51.2 \pm 12.4$ & $49.2 \pm 11.4$ \\
\hline Gender & $0.42 \pm 0.12$ & $0.94 \pm 0.23$ \\
\hline Marital status & $0.95 \pm 0.22$ & $0.88 \pm 0.33$ \\
\hline Level of education & $8.74 \pm 3.01$ & $8.57 \pm 3.92$ \\
\hline Household size & $6.97 \pm 2.64$ & $6.15 \pm 2.49$ \\
\hline Land size & $2.70 \pm 1.93$ & $2.35 \pm 1.67$ \\
\hline Occupation of the household head & $0.91 \pm 0.28$ & $0.88 \pm 0.33$ \\
\hline Farm household income (US \$ pm) & $290.62 \pm 22.83$ & $228.25 \pm 16.82$ \\
\hline Non-farm household income (US \$ pm) & $350.02 \pm 36.02$ & $96.37 \pm 18.47$ \\
\hline Access to extension services & $0.43 \pm 0.12$ & $0.16+0.02$ \\
\hline Access to credits services & $0.67 \pm 0.24$ & $0.03 \pm 0.02$ \\
\hline Access to formal AF training & $0.35 \pm 0.07$ & $0.12 \pm 0.02$ \\
\hline Access to information from conservancy groups & $0.62 \pm 0.12$ & $0.03 \pm 0.01$ \\
\hline Access to inputs from conservancy groups & $0.15 \pm 0.04$ & $0.04 \pm 0.02$ \\
\hline Frequency of extension visits & $1.69 \pm 1.14$ & $1.25 \pm 0.21$ \\
\hline
\end{tabular}

\section{RESUlts}

The socio-economic profile of the respondents in Machakos County of Kenya during the study is shown in Table 3. Both adopters and non-adopters were dominated by those aged 36-55 years as well as those aged over 55 years. Our sample had proportionally more females than males regardless of the status of agroforestry adoption. Most of the respondents were married. Educational level for majority of the respondent was primary and secondary levels. In terms of household size, majority of the adopters of agroforestry had household size ranging between 6-10 family members which were higher than the nonadopters. The land size ranged between 0.4 to 24 acres where the majority of the households had land size ranging between $2-5$ acres followed by those with less than 2 acres. The annual household farm income for $75 \%$ of the respondents ranged between US $\$ 50$ to 5000 while non farm income for majority of the respondents was often below US \$ 50 followed by income levels between US \$ 50 to 100 .

Table3. General characteristics of agroforestry 'adopter and non-adopter

\begin{tabular}{|c|c|c|c|c|c|}
\hline & & Agroforestry adopt & & Agroforestry no & adopters \\
\hline Variable name & Response category & $\begin{array}{l}\text { Frequency }(\mathrm{n}= \\
204)\end{array}$ & Percent & $\begin{array}{l}\text { Frequency }(\mathrm{n}= \\
44)\end{array}$ & Percent \\
\hline \multirow[t]{4}{*}{ Age (years) } & $18-25$ & 11 & 5.4 & 6 & 6.9 \\
\hline & $26-35$ & 28 & 13.7 & 8 & 18.2 \\
\hline & $36-55$ & 84 & 41.2 & 14 & 31.8 \\
\hline & $>55$ & 81 & 39.1 & 16 & 36.4 \\
\hline \multirow[t]{2}{*}{ Gender } & Female & 116 & 56.9 & 26 & 59.1 \\
\hline & Male & 88 & 43.1 & 18 & 40.9 \\
\hline \multirow[t]{2}{*}{ Marital status } & Single & 12 & 5.9 & 1 & 2.3 \\
\hline & Married & 192 & 94.1 & 43 & 97.7 \\
\hline \multirow[t]{4}{*}{ Level of education } & None & 5 & 2.5 & 7 & 15.9 \\
\hline & Primary & 112 & 54.9 & 18 & 40.9 \\
\hline & Secondary & 73 & 35.8 & 14 & 31.8 \\
\hline & Tertiary & 14 & 6.8 & 5 & 11.4 \\
\hline \multirow[t]{4}{*}{ Household size } & $<3$ & 3 & 1.5 & 0 & 0.0 \\
\hline & $3-5$ & 75 & 36.8 & 27 & 61.4 \\
\hline & $6-10$ & 105 & 51.5 & 17 & 38.6 \\
\hline & $>10$ & 21 & 10.3 & 0 & 0.0 \\
\hline \multirow[t]{2}{*}{ Land size } & $<2$ acre & 72 & 35.3 & 14 & 31.8 \\
\hline & $2-5$ acres & 106 & 52.0 & 26 & 59.1 \\
\hline
\end{tabular}


Socio-Economic and Institutional Factors Influencing Adoption of Agroforestry in Arid and Semi Arid (ASALs) Areas of Sub Saharan Africa

\begin{tabular}{|c|c|c|c|c|c|}
\hline & $5.1-10$ acres & 26 & 12.7 & 4 & 9.1 \\
\hline \multirow{5}{*}{$\begin{array}{l}\text { Farm income (US } \\
\$ \mathrm{pm})\end{array}$} & $<50$ & 18 & 8.8 & 3 & 6.9 \\
\hline & $50-100$ & 53 & 26.0 & 14 & 31.8 \\
\hline & $101-200$ & 43 & 21.1 & 14 & 31.8 \\
\hline & $201-500$ & 57 & 27.9 & 11 & 25.0 \\
\hline & $>500$ & 33 & 16.2 & 2 & 4.5 \\
\hline \multirow{5}{*}{$\begin{array}{l}\text { Non-farm income } \\
\text { (US \$ pm) }\end{array}$} & $<50$ & 68 & 33.3 & 17 & 38.6 \\
\hline & $50-100$ & 46 & 22.5 & 10 & 22.7 \\
\hline & $101-200$ & 29 & 14.2 & 7 & 15.9 \\
\hline & $201-500$ & 30 & 14.7 & 10 & 22.8 \\
\hline & $>500$ & 31 & 15.2 & 0 & 0.0 \\
\hline
\end{tabular}

The study established that $82.3 \%$ of the respondents adopted agroforestry practices while $17.7 \%$ were non adopters. The types of agroforestry practiced by the adopters are shown in Fig. 2. Majority of the respondents adopted boundary planting $(73.8 \%)$, hedgerow $(69.4 \%)$, woodlot $(53.2 \%)$ and scattered planting (51.2\%) while alley cropping was the least preferred agroforestry practice $(37.1 \%)$.

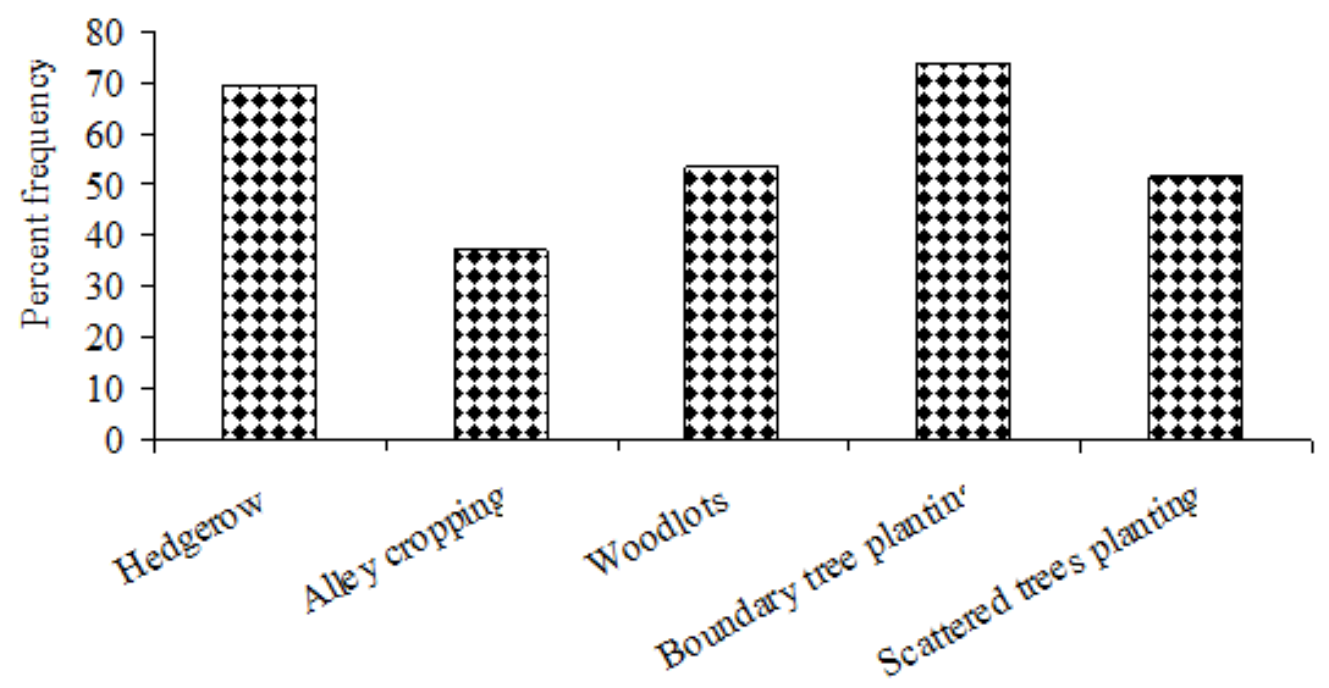

Fig2. Types of agroforestry practiced by the local community members who adopted the practice

The result of the binary logistic regression showing the relationship between 16 socioeconomic and institutional factors on adoption of agroforestry practices are shown in Table 4. The variables in the equation was described using $\mathrm{B}=1.534, \mathrm{SE}=0.166$, Wald $=85.161, \mathrm{P}=0.0000$ and $\operatorname{Exp}(4.636)$. The significant factors explaining the determinants of agroforestry adoption were levels of education, household size, access to credit and access to training.

Table4. Binary logistic regression showing the relationship between 16 socioeconomic and institutional factors on adoption of agroforestry practices

\begin{tabular}{|l|l|l|l|l|l|}
\hline Variables in the equation & Coefficient & S.E. & Wald & df & P-value \\
\hline Age & 0.248 & 0.231 & 1.151 & 1 & 0.283 \\
\hline Gender & -0.081 & 0.404 & 0.04 & 1 & 0.841 \\
\hline Marital status & -1.608 & 1.143 & 1.98 & 1 & 0.159 \\
\hline Level of education & $\mathbf{1 . 3 7 9}$ & $\mathbf{0 . 3 0 1}$ & $\mathbf{5 . 5 8 8}$ & $\mathbf{1}$ & $\mathbf{0 . 0 2 1}^{*}$ \\
\hline Household size & $\mathbf{1 . 2 1 9}$ & $\mathbf{0 . 3 9 2}$ & $\mathbf{9 . 6 7 9}$ & $\mathbf{1}$ & $\mathbf{0 . 0 0 2}^{* *}$ \\
\hline Land size & -0.561 & 0.333 & 2.831 & 1 & 0.092 \\
\hline Location & -0.511 & 0.321 & 2.674 & 1 & 0.095 \\
\hline Occupation of the household & -0.001 & 0.642 & 0.0043 & 1 & 0.998 \\
\hline Farm income & 0.261 & 0.175 & 2.221 & 1 & 0.136 \\
\hline Non farm income & 0.059 & 0.151 & 0.151 & 1 & 0.697 \\
\hline Access to extension & -1.001 & 0.616 & 2.641 & 1 & 0.104 \\
\hline
\end{tabular}


Socio-Economic and Institutional Factors Influencing Adoption of Agroforestry in Arid and Semi Arid (ASALs) Areas of Sub Saharan Africa

\begin{tabular}{|c|c|c|c|c|c|}
\hline Access to credit & 2.616 & 0.8 & 10.686 & 1 & $0.001^{* * *}$ \\
\hline Access to training & 1.682 & 0.844 & 3.974 & 1 & $0.046^{*}$ \\
\hline $\begin{array}{l}\text { Access to information from } \\
\text { conservancy group }\end{array}$ & -0.211 & 0.121 & 1.611 & 1 & 0.595 \\
\hline $\begin{array}{l}\text { Access to inputs from conservancy } \\
\text { group }\end{array}$ & 0.204 & 0.221 & 1.131 & 1 & 0.183 \\
\hline Frequency of extension visits & 0.073 & 0.33 & 0.048 & 1 & 0.826 \\
\hline Constant & -1.752 & 1.786 & 0.962 & 1 & 0.327 \\
\hline
\end{tabular}

${ }^{*} P<0.05,{ }^{* *} P<0.01,{ }^{* * *} P<0.001$

Adoption of agroforestry among household members and significant socio-economic and institutional factors are shown in Table 5. The study established that level of education was the significant factor and individual were 5.588 times likely adopt agroforestry than those without any education. In this study majority of the adopters were in the range of primary and secondary levels of education. Household size was 9.679 more likely to affect adoption of agroforestry where, most adopters of agroforestry were from large household size with 6-10 people. Access to credit was 10.686 times more likely to affect adoption where it was established that at least $8.8 \%$ of the adopters had access to credit while none of the non adopters accessed any form of credit. Finally household with access to formal training were 3.974 more likely to adopt agroforestry than those without access to training. We established that at least $28 \%$ of the adopters had access to formal training on agroforestry compared to only $4.5 \%$ of the non adopters.

Table5. Relationships between the significant socio-economic status and institutional factors and adoption of agroforestry in Machakos County

\begin{tabular}{|l|l|l|l|}
\hline \multirow{2}{*}{$\begin{array}{l}\text { Level } \\
\text { education }\end{array}$} & $\begin{array}{l}\text { \% agroforestry adopter }(\mathrm{n}= \\
204)\end{array}$ & $\begin{array}{l}\text { \% agroforestry non adopters }(\mathrm{n} \\
=44)\end{array}$ \\
& None & 2.5 & 15.9 \\
\cline { 2 - 4 } & Primary & 54.9 & 40.9 \\
\cline { 2 - 4 } & Secondary & 35.8 & 31.8 \\
\cline { 2 - 4 } & Tertiary & 6.9 & 11.4 \\
\hline \multirow{3}{*}{ Household size } & $<3$ & 1.5 & 0.0 \\
\cline { 2 - 4 } & $3-5$ & 36.8 & 61.4 \\
\cline { 2 - 4 } & $6-10$ & 51.5 & 38.6 \\
\cline { 2 - 4 } & $>10$ & 10.3 & 0.0 \\
\hline \multirow{2}{*}{$\begin{array}{l}\text { Access to credit } \\
\text { facilities }\end{array}$} & Yes & 8.8 & 0 \\
\cline { 2 - 4 } $\begin{array}{l}\text { Access to formal } \\
\text { AF training }\end{array}$ & Yes & 91.2 & 100 \\
\cline { 2 - 4 } & No & 27.9 & 9.5 \\
\hline
\end{tabular}

\section{DISCUSSION}

During the study, a total of $82.3 \%$ of the respondents adopted agroforestry practices which concurs with previous studies on adoption of agroforesty in similar regions (Makori 2017; Maluki et al. 2016; Nzilu 2015; Rotich et al. 2017), and appear to be higher than in other countries of Sub Saharan Africa (Ashiagbor et al. 2018; Franzel et al. 2001; Oloyede and Ayinde 2016). It is possible that the region being in humid dryland, encourages farmers to adopt the practices as ecosystem services derived from natural forests are not available. Most farmers adopted boundary planting (73.8\%), hedgerow $(69.4 \%)$ and scattered planting $(51.2 \%)$ while alley cropping was the least preferred agroforestry practice $(37.1 \%)$. This concurs with other studies that have indicated that farmers prefer hedgerow agroforestry which provides shelter, prevents frosts and act wind breaks (Kuyah et al. 2016; Lasco et al. 2014; Mbow et al. 2014; Mitigation 2010). A number of the farmers also adopted boundary planting as wind breakers and to demarcate boundaries of the farmers perhaps in order to avoid trespassers.

Binary logistic regression was chosen because to test the influence of the 16 socioeconomic and institutional factors on the adoption of agroforestry due to its ability to utilize both the continuous and categorical variables and or if they are not nicely distributed (Frölich 2006). When the 16 socioeconomic and institutional factors on adoption of agroforestry practices were tested it showed a 
combination level of education, household size, access to credit and access to training significantly affected adoption. This agrees with findings from other studies whereby, similar socio-economic characteristics of the smallholder farmers affected the adoption of agroforestry (Akpabio and Ibok 2009; Maluki et al. 2016; Mukungei et al. 2013; Oino and Mugure 2013). Education improves knowledge, awareness, management skills and extension services in agroforestry (Thangata 1996) leading to likelihood of adoption. In the study, agroforestry was adopted better among households with primary and secondary levels of education compared with those having higher educational qualifications. Although this in quite unexpected, it concurs studies within the Sub Saharan Africa (Nyanga et al. 2016; Rotich et al. 2017; Sood and Mitchell 2009). Although the literacy levels is supposed to determine the levels of agroforestry adoption, in most of the countries within the Sub Saharan Africa region, most people who have basic education appear to be the most active in agricultural adoptions. Majority of the adopters of agroforestry had household size ranging between 6-10 family members to provide labour. The best household size that favoured adoption of agroforestry was large household size with 6-10 people, suggesting that higher adoption rates of agroforestry were related to the availability of family labour. Large household size positively influences adoption of labor-demanding agricultural technologies since they have the ability to relax the labor limitations necessary in the course of introduction of new technologies. Labour from the majority of household members who fall in lower age brackets is restricted because these groups spend most of their time studying in schools and colleges. However, these studies are not in agreement with those of (Uisso and Masao 2016) who did not find any significant relationship between household size and agroforestry adoption and practices. The combinations of these factors have been highlighted by several studies to be crucial in providing the adopters with knowledge, manpower and technical ability to undertake agroforestry practices (Coulibaly et al. 2017).

As concern the institutional factors, access to credit facilities and access to formal agroforestry training significantly affected adoption of agroforestry in the study area similar to other studies (Kiptot et al. 2006; Mukungei et al. 2013). Extension strategies, including field schools, exchange visits and farmer training, are effective ways of disseminating agroforestry information. Unfortunately, agricultural extension officers concentrated on crops and animal production, while on the other hand, Forest Extension officers embarked on tree planting activities only. Many agricultural extension workers are not familiar with trees and shrub species that could fit in an agroforestry system. These agricultural trained extension agents have little knowledge about agroforestry trees with respect to their vernacular names, ecology, propagation, management and uses. On the other hand, forestry extension workers tend to view tree species from a purely "forestry" point of view, and neglect the needs and constraints identified by farmers. Most of the respondents in Kapsaret cited faulty extension services, with inadequate follow up visits or insufficient time for training and advice (Ipara 1993) observed that poor extension services and understaffing were the main bottlenecks to agroforestry technology adoption by women in Vihiga Division in Kenya. Likewise, farmers in Kapsaret believe that there is a direct influence of extension services.

\section{CONCLUSION}

The study determined that $82.3 \%$ of the respondents adopted agroforestry in the form of boundary planting (73.8\%), hedgerow (69.4\%), scattered planting (51.2\%) and alley cropping (37.1\%). The study established that level of education, household size, access to credit and formal training were the significant socio-economic and institutional factors affecting adoption of agroforestry. Highest level of adoption of agroforestry occurred among those with primary and secondary levels of education, increased with large household size with 6-10 people and was most adopted by households with access to credit facilities and formal agroforestry training. Based on the findings of study, we recommend: need for capacity building to raise farmers' level of awareness of the agroforestry practices; need for agroforestry extension services for the smallholder farmers on agroforestry adoption. Also the farmers need to be educated on the appropriate agroforestry practices.

\section{ACKNOWLEDGEMENTS}

The authors sincerely thank the Kenya Organization for Environmental Education (KOEE) through Faith Based Climate Change Education for Sustainable Development (FBCCESD) for their financial contribution to this study. We appreciate the Kenya Agricultural and Livestock Research Organization (KALRO) for the design and training of research assistants, field data collection and analysis. We also 
thank staff of Kenya Forest Service (KFS) for their assistance in identifying conservation groups for this study. Sincere gratitude must go to the local community members who provided the data.

\section{REFERENCES}

[1] Ajayi OC, Place F (2012) Policy support for large-scale adoption of agroforestry practices: experience from Africa and Asia. Agroforestry-The Future of Global Land Use, Springer, pp 175-201

[2] Akpabio IA, Ibok IP (2009) Agroforestry practices among male and female farmers in South-South, Nigeria. Small-Scale Forestry 8: 63-76

[3] Alavalapati J, Nair P, Barkin D (2001) Socioeconomic and institutional perspectives of agroforestry. World forests, markets and policies, Springer, pp 71-83

[4] Ashiagbor G, Oduro W, Thevathasan N, Gordon A, Gray R, Odame H (2018) Sustainable Land Resource Management with agroforestry: empirical evidence from the Sunyani West District of Ghana, West Africa. Sustainable Land Resource Management with agroforestry: empirical evidence from the Sunyani West District of Ghana, West Africa: 12-16

[5] Benjamin EO, Sauer J (2018) The cost effectiveness of payments for ecosystem services-Smallholders and agroforestry in Africa. Land use policy 71: 293-302

[6] Binam JN, Place F, Djalal AA, Kalinganire A (2017) Effects of local institutions on the adoption of agroforestry innovations: evidence of farmer managed natural regeneration and its implications for rural livelihoods in the Sahel. Agricultural and Food Economics 5: 2

[7] Brockington JD, Harris IM, Brook RM (2016) Beyond the project cycle: a medium-term evaluation of agroforestry adoption and diffusion in a south Indian village. Agroforestry systems 90: 489-508

[8] Brown SE, Miller DC, Ordonez PJ, Baylis K (2018) Evidence for the impacts of agroforestry on agricultural productivity, ecosystem services, and human well-being in high-income countries: a systematic map protocol. Environmental Evidence 7: 24

[9] Catacutan D, Van Noordwijk M, Nguyen T, Öborn I, Mercado A (2017) Agroforestry: contribution to food security and climate-change adaptation and mitigation in Southeast Asia. White Paper Bogor, Indonesia: World Agroforestry Centre (ICRAF) Southeast Asia Regional Program

[10] Coulibaly JY, Chiputwa B, Nakelse T, Kundhlande G (2017) Adoption of agroforestry and the impact on household food security among farmers in Malawi. Agricultural systems 155: 52-69

[11] Cox DR (2018) Analysis of binary data. Routledge

[12] Dalemans F, Muys B, Maertens M (2018) Adoption of agroforestry-based biofuel systems in South India.

[13] Dalemans F, Muys B, Maertens M (2019) Adoption Constraints for Small-scale Agroforestry-based Biofuel Systems in India. Ecological Economics 157: 27-39

[14] Fagerholm N, Torralba M, Burgess PJ, Plieninger T (2016) A systematic map of ecosystem services assessments around European agroforestry. Ecological Indicators 62: 47-65

[15] Fleming A, O’Grady AP, Mendham D, England J, Mitchell P, Moroni M, Lyons A (2019) Understanding the values behind farmer perceptions of trees on farms to increase adoption of agroforestry in Australia. Agronomy for Sustainable Development 39: 9

[16] Franzel S, Coe R, Cooper P, Place F, Scherr S (2001) Assessing the adoption potential of agroforestry practices in sub-Saharan Africa. Agricultural systems 69: 37-62

[17] Franzel S, Scherr S, Coe R, Cooper P, Place F (2002) Methods for assessing agroforestry adoption potential. Trees on the farm: assessing the adoption potential of agroforestry practices in Africa: 11-36

[18] Frölich M (2006) Non-parametric regression for binary dependent variables. The Econometrics Journal 9: 511-540

[19] Garrity DP (2004) Agroforestry and the achievement of the Millennium Development Goals. Agroforestry systems 61: 5-17

[20] Harrell FE (2015) Binary logistic regression. Regression modeling strategies, Springer, pp 219-274

[21] Ipara H (1993) Women and agroforestry in eastern Africa: Socio-economic factors affecting participation of women in rural Kenya. African Caribbean Institute, Hanover

[22] Kabwe G, Bigsby HR, Cullen R (2016) Why is adoption of agroforestry stymied in Zambia? Perspectives from the ground-up. 
[23] Kalaba KF, Chirwa P, Syampungani S, Ajayi CO (2010) Contribution of agroforestry to biodiversity and livelihoods improvement in rural communities of Southern African regions. Tropical rainforests and agroforests under global change, Springer, pp 461-476

[24] Kenya National Bureau of Statistics (2010) The 2009 Kenya population and housing census. Kenya National Bureau of Statistics

[25] Kiptot E, Franzel S, Hebinck P, Richards P (2006) Sharing seed and knowledge: farmer to farmer dissemination of agroforestry technologies in western Kenya. Agroforestry systems 68: 167-179

[26] Kuyah S, Öborn I, Jonsson M (2017) Regulating ecosystem services delivered in agroforestry systems. Agroforestry, Springer, pp 797-815

[27] Kuyah S, Öborn I, Jonsson M, Dahlin AS, Barrios E, Muthuri C, Malmer A, Nyaga J, Magaju C, Namirembe $S$ (2016) Trees in agricultural landscapes enhance provision of ecosystem services in Sub-Saharan Africa. International Journal of Biodiversity Science, Ecosystem Services \& Management 12: 255-273

[28] Lasco RD, Delfino RJP, Catacutan DC, Simelton ES, Wilson DM (2014) Climate risk adaptation by smallholder farmers: the roles of trees and agroforestry. Current Opinion in Environmental Sustainability 6: 83-88

[29] Makori NJ (2017) Analysis of socio-economic factors that affect agroforestry adoption among smallholders in Temiyotta Location, Nakuru County. Faculty of Arts, Department of Geography and Environmental Studies,

[30] Maluki J, Kimiti JM, Nguluu SN, Musyoki J (2016) Adoption levels of agroforestry tree types and practices by smallholders in the semi-arid areas of Kenya: A case of Makueni County.

[31] Matata P, Ajay O, Oduol P, Agumya A (2010) Socio-economic factors influencing adoption of improved fallow practices among smallholder farmers in western Tanzania. African journal of agricultural research 5: $818-823$

[32] Mbow C, Smith P, Skole D, Duguma L, Bustamante M (2014) Achieving mitigation and adaptation to climate change through sustainable agroforestry practices in Africa. Current Opinion in Environmental Sustainability 6: 8-14

[33] McAdam J, Curran E (2018) Adoption of Agroforestry Options in Land Use Policy Measures in Northern and Southern Ireland. Adoption of agroforestry options in land use policy measures in Northern and Southern Ireland: 78-81

[34] Meijer SS, Catacutan D, Ajayi OC, Sileshi GW, Nieuwenhuis M (2015) The role of knowledge, attitudes and perceptions in the uptake of agricultural and agroforestry innovations among smallholder farmers in sub-Saharan Africa. International Journal of Agricultural Sustainability 13: 40-54

[35] Mercer DE (2004) Adoption of agroforestry innovations in the tropics: a review. Agroforestry systems 61: 311-328

[36] Miller DC, Ordonez PJ, Baylis K, Hughes K, Rana P (2017) Protocol for an evidence and gap map. The impacts of agroforestry on agricultural productivity, ecosystem services, and human well-being in low-and middle-income countries: an evidence and gap map. Campbell collaboration

[37] Mitigation C (2010) Sustainable agroforestry potentials and climate change mitigation. Advances in Environmental Biology 4: 58-63

[38] Montagnini F, Metzel R (2017) The contribution of agroforestry to sustainable development goal 2: end hunger, achieve food security and improved nutrition, and promote sustainable agriculture. Integrating landscapes: Agroforestry for biodiversity conservation and food sovereignty, Springer, pp 11-45

[39] Mugenda OM, Mugenda AG (2003) Research methods. Quantitative and qualitative approaches: 46-48

[40] Mukungei PK, Arusei EJ, Mining PJ, Chedotum K, Cheserek GJ (2013) Socio-economic factors affecting farmers' decisions to adopt agro-silviculture in Turbo Division, Uasin Gishu County, Kenya. Journal of Emerging Trends in Economics and Management Sciences 4: 8-14

[41] Munsell JF, Addlestone BJ, Bukowski CJ, Nkembi L, Kingsly N, Moore EA (2018) Relationships between agroforestry and community development according to practitioners. Agroforestry systems 92: 1387-1396

[42] Mwase W, Sefasi A, Njoloma J, Nyoka BI, Manduwa D, Nyaika J (2015) Factors affecting adoption of agroforestry and evergreen agriculture in Southern Africa. Environment and Natural Resources Research 5: 148

[43] Nardi PM (2018) Doing survey research: A guide to quantitative methods. Routledge 
[44] Nyanga A, Kessler A, Tenge A (2016) Key socio-economic factors influencing sustainable land management investments in the West Usambara Highlands, Tanzania. Land Use Policy 51: 260-266

[45] Nzilu WB (2015) Farmer's perception and its impacts on adoption of new agroforestry tree (Gliricidia sepium) in Mwala Division, Kenya. Kenyatta University,

[46] Oino P, Mugure A (2013) Farmer-oriented factors that influence adoption of agroforestry practices in Kenya: Expériences from Nambale District, Busia County. International Journal of Science and Research 2: 450456

[47] Oloyede A, Ayinde O (2016) Assessing adoption of agroforestry practices among small-scale farmers in North Central, Nigeria.

[48] Owombo P, Idumah F, Adepoju A (2018) Analysis of Farmers' Perception and Adoption of Agroforestry Technology as Climate Change Mitigation Strategy in Edo State, Nigeria. World News of Natural Sciences 21: $16-27$

[49] Pattanayak SK, Mercer DE, Sills E, Yang J-C (2003) Taking stock of agroforestry adoption studies. Agroforestry systems 57: 173-186

[50] Place F, Ajayi OC, Torquebiau E, Detlefsen G, Gauthier M, Buttoud G (2012) Improved policies for facilitating the adoption of agroforestry. Agroforestry for Biodiversity and Ecosystem Services-Science and Practice, IntechOpen,

[51] Rotich J, Sirmah P, Edward M, Odwori P (2017) Agroforestry trees in Kapsaret, Kenya: Socio-economic perspectives influencing availability, preference and utilization. International Journal of Agroforestry and Silviculture 5

[52] Sangeetha R, Shanmugam T, Nandhini SU (2016) Factors Affecting Adoption Rate of Agro Forestry Technologies in Tamil Nadu. Agricultural Economics Research Review 29: 307

[53] Saqib M, Akhtar J, Abbas G, Murtaza G (2019) Enhancing Food Security and Climate Change Resilience in Degraded Land Areas by Resilient Crops and Agroforestry. Climate Change-Resilient Agriculture and Agroforestry, Springer, pp 283-297

[54] Sharma G, Sharma E (2017) Agroforestry Systems as Adaptation Measures for Sustainable Livelihoods and Socio-economic Development in the Sikkim Himalaya. Agroforestry, Springer, pp 217-243

[55] Sood KK, Mitchell CP (2009) Identifying important biophysical and social determinants of on-farm tree growing in subsistence-based traditional agroforestry systems. Agroforestry systems 75: 175-187

[56] Thangata P (1996) Resource Poor Farmers' Perception of Agroforestry Practices-A Case Study of Malawi. Unpublished Master's Thesis, University of Edinburgh, Scotland, UK

[57] Uisso A, Masao C (2016) Women participation in agroforestry farming system: A strategy towards poverty reduction in Morogoro rural district, Tanzania. Ethiopian Journal of Environmental Studies and Management 9: $613-624$

[58] Waldron A, Garrity D, Malhi Y, Girardin C, Miller D, Seddon N (2017) Agroforestry can enhance food security while meeting other sustainable development goals. Tropical Conservation Science 10: 1940082917720667

[59] Zerihun MF, Muchie M, Worku Z (2014) Determinants of agroforestry technology adoption in Eastern Cape Province, South Africa. Development Studies Research An Open Access Journal 1: 382-394

Citation: Benjamin Mutuku Kinyili, et.al., " Socio-Economic and Institutional Factors Influencing Adoption of Agroforestry in Arid and Semi Arid (ASALs) Areas of Sub Saharan Africa", International Journal of Forestry and Horticulture (IJFH), vol. 6, no. 1, pp. 8-18, 2020. Available: DOI: http://dx.doi.org/ 10.20431/ 24549428.0601002

Copyright: (c) 2020 Authors. This is an open-access article distributed under the terms of the Creative Commons Attribution License, which permits unrestricted use, distribution, and reproduction in any medium, provided the original author and source are credited. 